\title{
Research about the Effection of Incubated Enterprises Business Network on the Enterprise Performance
}

\author{
Yunhe Li \\ School of Business Administration \\ Dalian University of Technology \\ Dalian, China \\ 2205055137@qq.com \\ Li Zuo* \\ School of Business Administration, \\ Dalian NationalitiesUniversity \\ Dalian, China \\ 798139124@qq.com \\ *Corresponding author
}

\author{
Liyan Tang \\ School of Business Administration \\ Dalian University of Technology \\ Dalian, China
}

\begin{abstract}
Entrepreneurship is increasingly becoming one of the driving forces of regional economic development, and incubated enterprises, as a special type of start-ups, is also playing an important role in the regional economy. In this paper, we take the incubatedd enterprise business network as our research object, and we describe the business network from the size, strength and heterogeneity three angles. We explore the relationship between business networks and enterprise performance through the empirical research, and we found that the network size, network strength and network heterogeneity of incubatedd enterprise business network has a significant positive impact on the business performance. In the end, we put forward several suggestions for the further development of the incubated enterprises.
\end{abstract}

Keywords- Incubated Enterprises; Business Networking; Enterprise Performance

\section{INTRODUCTION}

Entrepreneruship is becoming one of the driving forces of the regional economic development. And it is difficult to ensure the start-ups have a good development because of the "new","small","instabliliy" and other defects. The incubators provide a good foundation for the new ventures. From the resource-based view, the incubators also provide a good platform for business network of incubated enterprise. On the one hand, business network provide a stable commercial resources for the incubated enterprise, which promotes the development and progress of incubated enterprise. On the other hand, business network also help the entrepreneurs change the status from "hero in the bush" to "successful entrepreneur". In this paper, we focus on the incubated enterprise, a special type of start-ups, study the business network from the network size, network strength and network heterogeneity three dimensions and explore the relationship between the incubated enterprise business network and enterprise performance, in order to enrich the related research about incubation theory and enterpreneurship theory.

\section{LITERATURE REVIEW}

The concept of "incubator" in the economic field was first used by the American scholar Joseph - Mancuso, and he founde the word's first incubator named Bette Via industrial center. With the development of the concept and operation of incubator, incubators make a great contribution to the development and progress of global high-tech industry, and they improve the effectivenss of regional innovation and entrepreneurship activities. In China, the first incubator was founde in Wuhan, 1987, and now, the incubator play an important role in regional development. With the development and improvement of incubators, the incubation network has become the mainstream. Incuabion network can give full play to the social newwork relatioinship, scale economies and scope economies and many other advantages. Incubated enterprise, as the clients of incubator, can get a variety of resources from the incubator ,including the cheap space, cheap rent,management,policies, information,culture and brand and so on. This is the big difference between the incubated enterprises and start-ups in general. The incubated enterprise could enjoy more resources on the basis of the "location advantages". Moreover, the incubated enterprises must be the high-tech start-ups, the government document has a clear provision. And there are relative extensive research about the enterprise performance, and most of the study are describe the performance from the profitability,growth and innovation.

The research about the relationship between incubated enterprise business network and enterprise performance has make a preliminary results. Through the investigation and research of 137 start-ups in the aviation technical field, Lee and Lee (2001) found that business network has some signification impact on the performance [1].the research from Zheng Muqiang and $\mathrm{Xu}$ Zongling (2009) has proved that the outside business network has a positive effect on its techonoly innovation, and then impact the performance. Zhao Wenhong, Sun Wanqing and Wang Yao (2013), using the data from 154 
companies in the Xi'an High-tech Industrial Development Zone and taking the contact frequency as the metrics of network, tested and verified that the personal network and business network of enterprenerus also impact the venture performance.

The existing research studies provide a good theoretical framework for our study. And in this paper, we focus on the incubated enterprises, a special type of start-ups, and study the business network from the network size, network strength and network heterogeneity three dimensions and explore the relationship between the incubated enterprise business network and enterprise performance, in order to enrich the related research about incubation theory, social network theory and enterpreneurship theory.

The following picture shows the research framework of this paper.

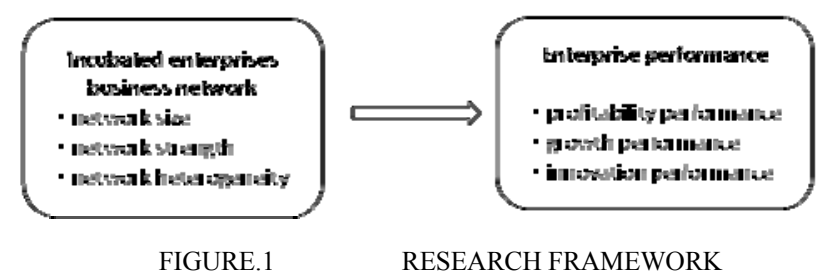

\section{HYPOTHESES}

The business network can not only provide the necessary for companies, but also strengthen the communication and interaction between enterprises, and promote the development of enterprises. This paper focus on the business network of incubated enterprises, study the business network from the network size, network strength and network heterogeneity three dimensions, and explore the relationship between the incubated enterprise business network and enterprise performance. Taking the relevant research of the entrepreneurial performance, the measurement of enterprise performance contains three parts, the profitability performance, growth performance, and innovation performance.

(1) The impact of netwokr size of incubated enterprises business network on the enterprise performace.

Business network size describes the overall size of the business network. And the size of the network, to a certain extent, reflects the amout of resources that the enterprises can get from the outside. In general, the more organizations establishing a newrok with the enterprise, the more resources the company can get. And along with the development of the enterprise, the demand of resources will be also growing. Baum (2000)believed that,the larger the size of network is ,the more relatinship the enterprise can enjoy[2] Rowley, Behrens \& Krackliardt (2000) thought that there was scale economies in the network[3] and with the development of network, the performance would also improve. At the same time, some scholars also proved the positive relationship between network size and enterprise performance, through differernt samples.

In summary, we make the following assumptions:
H1: the network size of incubated enterprises business networks has a significant positive impact on business performance.

H1a: the network size of incubated enterprises business networks has a significant positive impact on the profitability performance.

H1b: the network size of incubated enterprises business networks has a significant positive impact on the growth performance.

H1c: the network size of incubated enterprises business networks has a significant positive impact on innovation performance.

(2) The impact of netwokr strength of incubated enterprises business network on the enterprise performace.

The network strength of incubated enterprises business network reflects the frequency amont the network members [14].on the different research persepective, the conclusions about relationship between the network strength and enterprise performance are different.

On the one hand, Burt (2004) believed that the weak tie between netwoks could enrich the types of resources, which could help the companies grow [4]. Nooteboom (2004) drew a conclusion that the weak link is more helpful for the development of enterprises [5]. On the other hand, Krackhardt (1992) , one representative of the "strong tie advantage theory", argued that the higher the network strength was ,the closer the members conneted, and the better performace the enterprises would receive[6]. The research from Lavie (2007) was also shown that there was a positive relationship between network strength and firm performance[7]. Zhao Di (2009) also believed that the stronger the network strength is, the more ability the company could enjoy to get resources and knowledge, which would promote the company.

In this paper, we tend to the latter view, and we think that the stronger the network strength is, the better performance the incubated enterprises can receive. So, we put forward the following assumptions:

$\mathrm{H} 2$ : the network strength of incubated enterprises business networks has a significant positive impact on business performance.

H2a: the network strength of incubated enterprises business networks has a significant positive impact on the profitability performance.

$\mathrm{H} 2 \mathrm{~b}$ : the network strength of incubated enterprises business networks has a significant positive impact on the growth performance.

H2c: the network strength of incubated enterprises business networks has a significant positive impact on innovation performance.

(2) The impact of network heterogeneity of incubated enterprises business network on the enterprise performace.

Different from the network size and network strength, the network heterogeneity describe the types of business partners 
and the degree of difference among the resources. Johannisson et al (2001) found that the different types of network parnters had a significant impact on the corporate profit margins [8]. And scholars also pointed that the heterogenerity of resources could provide more opportunities for the company to combiane the elements and promote the technological innovation. In additon, Liao and Welsch (2000), using the National SME Database Research Group study data,found that network heterogeneity had a significant impact on the company growth willingness[9].Wu Aiqi(2004) and Ma Gang(2005), using different amples, verified the network heterogeneity had a positive impact on its growth and development.

In summary, we make the following assumptions:

H3: the network heterogeneity of incubated enterprises business networks has a significant positive impact on business performance.

H3a: the network heterogeneity of incubated enterprises business networks has a significant positive impact on the profitability performance.

$\mathrm{H} 3 \mathrm{~b}$ : the network heterogeneity of incubated enterprises business networks has a significant positive impact on the growth performance.

$\mathrm{H} 3 \mathrm{c}$ : the network heterogeneity of incubated enterprises business networks has a significant positive impact on innovation performance.

\section{STUDY DESIGN AND EMPIRICAL ANALYSIS}

\section{A. Questionnaire Design And Variable Measurement}

In this paper, we use field research to obtain data. the survey questionnair mainly includes incubated enterprises business network and enterprise performance.Among them, with reference to the social network research, the measurement of business network was portrayed from the network size, network strength and network heterogeneity three dimensions, and the main contents include the number of business members the frequency of commercial communication and the differences among the scale, the main business, technology and other aspcts. And about the enterprise performance, taking the reference to the past research, were measured from the profitable performance, growth performance and innovative performance, and the main contents of measurements are market share, net income ratio, ROI, Sales growth rate, Net income growth rate, Market share growth rate, capital turnover rate, the number of patent applications, the number of new products, the speed of new product development and the proportion of new product output and so on. Moreover, we take the company age, number of employees and revenue as control variable, in order to ensure the validity of our research.

\section{B. Sample Description and Analysis of Reliability and Validity}

Through the field research of Dalian D-D Innovation Center, High-Tech Innovation Service Center and other national science and technology business incubators,we send out 252 questioinnaires, and we received 179,among them, 168 questionairs were effective. At the same time, we use the SPSS17.0 to verify the data. And we found both the reliability and validity passed the test. This showed that the reliability and validity were good, and we could do the following research. The test vaule was shown in table1.

\section{TABLE. 1 THE RESULTS OF RELIABILITY TEST AND VALIDITY TEST}

\begin{tabular}{|c|c|c|c|}
\hline \multicolumn{4}{|c|}{ Results of Reliability Test and Validity Test } \\
\hline \multicolumn{2}{|c|}{ Variable } & Cronbach's $\alpha$ & KMO \\
\hline \multirow{3}{*}{ Business network } & Network size & .908 & \multirow{3}{*}{.862} \\
\hline & $\begin{array}{l}\text { Network } \\
\text { strength }\end{array}$ & .902 & \\
\hline & $\begin{array}{c}\text { Network } \\
\text { heterogeneity }\end{array}$ & .884 & \\
\hline \multirow{3}{*}{$\begin{array}{c}\text { Enterprise } \\
\text { performance }\end{array}$} & $\begin{array}{l}\text { Profitability } \\
\text { performance }\end{array}$ & .777 & \multirow{3}{*}{.874} \\
\hline & $\begin{array}{c}\text { Growth } \\
\text { performance }\end{array}$ & .899 & \\
\hline & $\begin{array}{l}\text { Innovation } \\
\text { performance }\end{array}$ & .776 & \\
\hline
\end{tabular}

\section{The Discussions of Regression Analysis Results}

In this paper, we take the network size, network strength and network heterogeneity as independent variables, and the profitability performance, growth performance and innovative performance as the dependent variables. We use the regression analysis to explore the relationship between incubated enterprise business network and firm performance. The results are shown in table 3 , contain six models.

There are three comparion groups, and they are modell and model2, model 3 and model 4, model 5 and model 6 . From the results, we can see that, the R2 value all increased significantly. In the profitability performance regression analysis, the R2 value increased from 0.255 to 0.399 ; in the growth performance regressioin analysis, the value of $\mathrm{R} 2$ increased from 0.417 to 0.567 ; and in the innovation performance regression analysis, the value of $\mathrm{R} 2$ increased from 0.206 to 0.109. All of these indicated that the explanatory power of the models has been strengthened. Meanwhile, the value of $F$ in the six models all reached significant level, which indicated the model fit well.

In the table3, we can see that the influence coeffieciet Bbetween incubated enterprises business network size and profitability performance, growth performance and innovation performance were $0.216(p<0.01) 、 0.218(p<0.001)$ 、和 $0.205(p<0.01)$, all of them have reached a significant level. And this indicated that the incubated enterprises business network netwok size has a significant positive influence on the entrepreneurial performance, and the assumption $\mathrm{H} 1, \mathrm{H} 1 \mathrm{a}, \mathrm{H} 1 \mathrm{~b}$ and $\mathrm{H} 1 \mathrm{c}$ were verified.

And the influence coeffieciet $\beta$ between network strength of incubated enterprises business network and profitability performance, growth performance and innovation performance were $0.251 \quad(p<0.01), 0.246(p<0.001)$ and 0.334 $(p<0.001)$,all of them have reached a significant level. And this indicated that the incubated network strength of incubated enterprises business network has a significant positive influence on the entrepreneurial performance, and the assumption $\mathrm{H} 2, \mathrm{H} 2 \mathrm{a}, \mathrm{H} 2 \mathrm{~b}$ and $\mathrm{H} 2 \mathrm{c}$ were verified. 
At last, the influence coeffieciet Bbetween network heterogeneity of incubated enterprises business network and profitability performance, growth performance and innovation performance were $0.145(\mathrm{p}<0.05), 0.167 \quad(\mathrm{p}<0.01)$ and $0.182(p<0.01)$, all of them have reached a significant level. And this indicated that the incubated network heterogeneity of incubated enterprises business network has a significant positive influence on the entrepreneurial performance, and the assumption $\mathrm{H} 3, \mathrm{H} 3 \mathrm{a}, \mathrm{H} 3 \mathrm{~b}$ and $\mathrm{H} 3 \mathrm{c}$ were verified.

\section{TABLE 2 RESULTS OF REGRESSION ANALYSIS}

\begin{tabular}{|c|c|c|c|c|c|c|}
\hline & \multicolumn{2}{|c|}{$\begin{array}{l}\text { Profitability } \\
\text { performance }\end{array}$} & \multicolumn{2}{|c|}{$\begin{array}{c}\text { Growth } \\
\text { performance }\end{array}$} & \multicolumn{2}{|c|}{$\begin{array}{l}\text { Innovation } \\
\text { performance }\end{array}$} \\
\hline & $\begin{array}{c}\text { model } \\
1\end{array}$ & $\begin{array}{c}\text { model } \\
2\end{array}$ & $\begin{array}{c}\text { model } \\
3\end{array}$ & $\begin{array}{c}\text { model } \\
4\end{array}$ & $\begin{array}{c}\text { model } \\
5\end{array}$ & model6 \\
\hline $\begin{array}{c}\text { company } \\
\text { age }\end{array}$ & $.403^{*}$ & $.341+$ & .090 & .031 & -.030 & -.114 \\
\hline $\begin{array}{l}\text { the number } \\
\text { of employees }\end{array}$ & $-.347+$ & $-.484^{*}$ & .261 & .114 & .203 & .040 \\
\hline revenue & $.434^{*}$ & $.350^{*}$ & $.312+$ & .228 & .289 & .202 \\
\hline network size & & $.216^{* *}$ & & $\begin{array}{c}.218^{* *} \\
*\end{array}$ & & $.205 * *$ \\
\hline $\begin{array}{l}\text { network } \\
\text { strength }\end{array}$ & & $.251 * *$ & & $\begin{array}{c}.246^{* *} \\
* \\
\end{array}$ & & $.334 * * *$ \\
\hline $\begin{array}{c}\text { network } \\
\text { heterogeneit } \\
\mathbf{y} \\
\end{array}$ & & $.145^{*}$ & & $.167^{* *}$ & & $.182 * *$ \\
\hline $\mathbf{R}^{2}$ & .255 & .399 & .417 & .567 & .206 & .409 \\
\hline Adjusted R ${ }^{2}$ & .241 & .377 & .406 & .551 & .191 & .387 \\
\hline F Change & 18.688 & 12.900 & 39.025 & 18.662 & 14.157 & 18.475 \\
\hline $\begin{array}{c}\text { Sig. F } \\
\text { Change }\end{array}$ & .000 & .000 & .000 & .000 & .000 & .000 \\
\hline
\end{tabular}

NOTE: $* * *$ indicates significant $\mathrm{p}<0.001, * *$ indicates significant $\mathrm{p}<0.01, *$ indicates significant $\mathrm{p}<0.05,+$ indicates significant $\mathrm{p}<0.1$

\section{CONCLUSION AND DISCUSSION}

In this paper, we focus on the incubated enterprise, study the business network from the network size, network strength and network heterogeneity three dimensions,mesure the enterprise performance from profitability performance, growth performance and innovation performance three sides, and we use an empirical study to exlore the relationship between the incubated enterprise business network and enterprise performance. In the end, we get the following coclusion: the incubated enterprises business networks has a significant positive impact on enterprise performance. For the network size of incubated enterprises business networks, it has has a significant positive impact on the profitability performance, growth performance and innovation performance. For the etwork strength of incubated enterprises business networks, it also has has a significant positive impact on the profitability performance, growth performance and innovation performance. And for the network heterogeneity of incubated enterprises business networks, it has has a significant positive impact on the profitability performance, growth performance and innovation performance too. These conclusions are consistent with the previous research findings. At the same time, this paper provides an additional research about the relationship between the business network and enterprise performance, from the network size, network strength and network heterogeneous three dimensions.
For the incubated enterprises, the method of enlarging the network size, strengthening the network strength and enriching the species of network will improve the enterprise performance effectively. On the one hand ,it expand the resources scale of the enterprises by enlarging the network size; on the other hand, strengthening the network strength can consolidate the relationship among the business memebers , and promote the sharing and circulation of knowledege, skills and resources and other necessary elements among the companies.meanwhile, raising the network heterogeneity can bring more kinds of resources for companies to do innovation activities, and thus the devolpment of the enterprises will be better.

It also should be noted that there are some shortcomings and limitations in this paper. In the future research,we could do a comparative study between the incubated enterprises and gernerel start-ups, in order to find out the similarities and differents; moreover, the elements that have impact on the enterprise performance are multiple, and in the future,we could do a multidimensional exploring research in order to make a clearer comprehension of the business network and enterprise performance.

\section{ACKNOWLEDGMENT}

This research was financially supported by Project 71303031 and Project 71173027 supported by the National Natural Science Foundation of China

\section{REFERENCES}

[1] Lee C,Lee K. internal capabilities ,external networks, and performance: A study on technology-based vetures.[J] Strategic Management Journal,2001,22(1):615-640

[2] Baum J.Calabrese T,Silverman B..Don't Go it alone: Aliance network composition and startups' performance in Canadian biotechnology. Strategic Management Journal, 2000,(21):267-294

[3] RowleyT,BehrensD, KrackhardtD. Redundant governance structures: ananalysis of structural and relational embeddedness in the steel and semiconduc-torindustries.StrategicManagementJournal, 2000, 21(3):369-386.

[4] Burt R.S..Structural Hole and Good Ideas.American Journal of Sociology,2004,(110):349-399

[5] Nooteboom V..A Gilsing Density and Strength of Ties in Innovation Networks:Acompetence and Governance View,2004(4):78

[6] Krackhardt D..The Strength of Strong Ties: The Importance of Philos in Organization,in N.Nohria and R.G.Eccles(Eds.),Networks and Organization: structure ,Form, and Action,Boston,MA:Harvard and Business School Press, 1992,216-239

[7] LavieD.Alliance portfolios and firm performance:a study of value creation and appropriation in the U.S. software industry. StrategicManagementJournal. 2007,28(12):1187-1212

[8] Johannisson, B. Ramirez-Pasillas, Networking for Entrepreneurship: Building a Topography Model of Human, Social and Cultural Capital. Presented on Babson College Entrepreneurship Research Conference, Jonkoping, Sweden, June ,2001.

[9] Liao J.M,Welsch, H. Social Capital And Growth Intention: The Role Of Entrepreneurial Networks In Technology-Based New Ventures. Frontiers of Entrepreneurship Research,Babson Colege, Mass,2000. 